\section{Overgangen fra digitoksin til digoksin i årene 2011-13}

\author{
ORIGINALARTIKKEL

\section{KNUT LIEN} \\ Institutt for klinisk og molekylær medisin \\ Norges teknisk-naturvitenskapelige universitet \\ og \\ Avdeling for klinisk farmakologi \\ St. Olavs hospital \\ Han har bidratt med utforming av studien, litteraturs $\varnothing k$, bearbeiding og tolkning av data og \\ utarbeiding av manusutkast. \\ Knut Lien er medisinstudent. \\ Forfatter har fylt ut ICMJE-skjemaet og oppgir ingen interessekonflikter.
}

\section{OLAV SPIGSET}

Avdeling for klinisk farmakologi St. Olavs hospital

og

Institutt for klinisk og molekylær medisin

Norges teknisk-naturvitenskapelige universitet

Han har bidratt med idé, utforming av studien, veiledning, litteratursøk, bearbeiding og tolkning av data, revisjon av manus og godkjenning av innsendte manusversjon.

Olav Spigset er dr.med., spesialist i klinisk farmakologi, overlege og professor.

Forfatter har fylt ut ICMJE-skjemaet og oppgir ingen interessekonflikter.

\section{ANDREAS AUSTGULEN WESTIN}

Avdeling for klinisk farmakologi

St. Olavs hospital

Han har bidratt med datainnsamling og -bearbeiding, revisjon av manus og godkjenning av innsendte manusversjon.

Andreas Austgulen Westin er spesialist i klinisk farmakologi og overlege. Forfatter har fylt ut ICMJE-skjemaet og oppgir ingen interessekonflikter.

\section{LARS SLØRDAL}

E-post: lars.slordal@ntnu.no Institutt for klinisk og molekylær medisin Norges teknisk-naturvitenskapelige universitet og

Avdeling for klinisk farmakologi

St. Olavs hospital

Han har bidratt med idé, utforming av studien, veiledning, litteratursøk, tolkning av data, revisjon av manus og godkjenning av innsendte manusversjon.

Lars Slørdal er dr.med., spesialist i klinisk farmakologi, professor og overlege.

Forfatter har fylt ut ICMJE-skjemaet og oppgir ingen interessekonflikter. 


\section{BAKGRUNN}

Tilbaketrekkingen av digitoksin og overgangen til digoksin rundt 2012 kan ha ført til økt helserisiko for digitalisbehandlede pasienter. Målet med denne studien var å følge pasienter på individnivå gjennom bytteprosessen.

\section{MATERIALE OG METODE}

Serumkonsentrasjoner av digitoksin og digoksin, målt ved Avdeling for klinisk farmakologi ved St. Olavs hospital i perioden 1.1.2011-31.12.2013, ble gjennomgått. Pasienter som hadde skiftet fra digitoksin til digoksin og fått serumkonsentrasjoner av begge legemidler målt $\mathrm{i}$ dette tidsrommet, ble inkludert.

\section{RESULTATER}

Totalt ble 304 pasienter, 1686 prøver og 1858 serumkonsentrasjonsanalyser inkludert i studien. Det ble målt terapeutiske serumkonsentrasjoner hos 171 pasienter (56,3\%) før byttet og 176 (57,9\%) etter byttet. 108 pasienter (35,5\%) hadde terapeutiske konsentrasjoner både før og etter byttet. For $58,9 \%$ av pasientene medførte byttet en reduksjon i serumkonsentrasjon av digitalis, beregnet som digoksinekvivalenter. Andelen pasienter med antatt supraterapeutiske konsentrasjoner gikk ned fra 43,1\% til 33,9\%, men samtidig gikk andelen pasienter med toksiske serumkonsentrasjoner opp fra o,3 \% til 3,0 \%.

\section{FORTOLKNING}

Til tross for at byttet for mange førte til en reduksjon i dose og serumkonsentrasjon, kan et betydelig antall pasienter ha blitt utsatt for fare som følge av overgangen.

Digitalisglykosider har vært i bruk i over 200 år og benyttes fortsatt ved behandling av atrieflimmer og hjertesvikt (1). Hvorvidt nytten av disse legemidlene veier opp for de potensielle farene ved å bruke dem, er omdiskutert. En placebokontrollert studie, gjennomført av The Digitalis Investigation Group, konkluderte med at digitalisterapi kan bidra til å redusere symptomtrykket ved hjertesvikt, men uten å påvirke dødeligheten (2).

Studier har vist at serumkonsentrasjoner av digoksin over 1,2 nmol/l, som tilsvarer øvre grense i dagens referanseområde, er assosiert med økt dødelighet (3). Bivirkninger ved overdosering av digitalisglykosider er i hovedsak uspesifikke og inkluderer asteni, synsforstyrrelser, muskelsvakhet, kvalme og anoreksi. I tillegg kan midlene forårsake kardiale bivirkninger, som for eksempel dødelige rytme- eller ledningsforstyrrelser (4).

I desember 2011 ble digitalisglykosidet digitoksin avregistrert i Norge. Pasienter som ble behandlet med digitoksin ble anbefalt å bytte til det gjenværende kommersielt tilgjengelige digitalisglykosidet digoksin. Statens legemiddelverk utarbeidet en veileder som beskrev hvordan overgangen skulle gjennomføres (5). Rådene fra Legemiddelverket er oppsummert i ramme 1 .

\section{Ramme 1 Legemiddelverkets anbefalinger ved overgangen fra digitoksin}

\section{til digoksin rundt $2012(5)$}

- Digitoksin seponeres i syv dager før oppstart av digoksin

- Ved samlet ukedose av digitoksin 175-349 $\mu \mathrm{g} / \mathrm{uke}$ anbefales $875 \mu \mathrm{g}$ digoksin/uke (125 $\mu \mathrm{g} / \mathrm{dag})$

- Ved samlet ukedose av digitoksin 350-70o $\mu \mathrm{g} / \mathrm{uke}$ anbefales $1750 \mu \mathrm{g}$ digoksin/uke (250 $\mu \mathrm{g} / \mathrm{dag}$ ) 
- Hos pasienter med $ø \mathrm{kt}$ følsomhet for digoksin vurderes en samlet ukedose på 437,5 $\mu \mathrm{g}$ $(62,5 \mu \mathrm{g} / \mathrm{dag})$ eller lavere

- Digoksin- og kaliumnivåer følges nøye hos pasienter med kronisk nyresykdom

- Serumkonsentrasjonsmåling gjennomføres henholdsvis 7 og 14 døgn etter oppstart av digoksin. Ytterligere målinger vurderes individuelt

I to studier har man tidligere diskutert ulike aspekter ved overgangen fra digitoksin til digoksin i Norge (6, 7), men ingen har fulgt enkeltpasienter. Målet med vår studie var å følge pasienter på individnivå for å undersøke hvordan digitaliskonsentrasjonene varierte gjennom bytteprosessen og forsøke å relatere nivåene til potensiell helserisiko.

\section{Materiale og metode}

Materialet som ligger til grunn for studien er samlet inn fra databasen der resultatene fra rutineanalyser av prøver for digitoksin og digoksin sendt til Avdeling for klinisk farmakologi ved St. Olavs hospital er lagret.

Innledningsvis opprettet vi en datafil med alle serumkonsentrasjonsanalyser av digitoksin og av digoksin gjennomført i tidsperioden 1.1.2011-31.12.2013. Identifiserbar

pasientinformasjon ble slettet, pasientens alder og kjønn registrert og hver pasient tildelt et unikt løpenummer. Denne filen inneholdt 8717 serumkonsentrasjonsanalyser fra 1 803 pasienter. Fra filen ekskluderte vi pasienter som kun hadde fått målt enten digitoksin eller digoksin, pasienter der vi ikke hadde opplysninger om inntatt middel og/eller dose, pasienter som hadde overdosert med hensikt, pasienter som hadde byttet fra digoksin til digitoksin (dvs. motsatt vei av det vi ønsket å studere) og pasienter som var under 18 år. Etter dette inneholdt den endelige filen 1686 prøver fra 304 pasienter. Av de 1686 prøvene var 172 analysert for både digoksin og digitoksin i én og samme prøve, slik at totalantallet analyser var 1858 .

I utvalget registrerte vi individuell informasjon om alder ved byttet, kjønn, inntatt legemiddel, dosering (omregnet til samlet ukedose) og serumkonsentrasjon av digitoksin og digoksin. Ingen prøver ble ekskludert på grunnlag av tidsintervall fra siste doseinntak til prøvetaking eller fravær av opplysninger om dette. Vi forutsatte at all prøvetaking var gjennomført etter vanlig rutine, altså medikamentfastende før inntak av morgendose. Samtlige analyser av digitoksin og digoksin ble utført med en kommersielt tilgjengelig immunologisk metode (Kinetic Interaction of Particles in Solution, KIMS) på et Cobas Integra-analyseinstrument (Roche Diagnostics, Mannheim, Tyskland).

For å ekskludere målinger som ikke var relatert til legemiddelbyttet, brukte vi i våre beregninger kun den digitoksinanalysen som lå nærmest byttet i tid, samt analyser av digoksin som var tatt innen tre måneder etter overgangen. Vi registrerte samtidig tidsintervallet mellom siste analyse av digitoksin og første analyse av digoksin. Hos pasienter med mer enn én digoksinanalyse etter byttet registrerte vi også tidsintervallet mellom de to første målingene.

For digoksinanalyser med Cobas Integra oppgis det i pakningsvedlegget en kryssreaktivitet på $7,7 \%$ ved en digitoksinkonsentrasjon på 63,9 nmol/l (8). For å kompensere for dette reduserte vi serumkonsentrasjonen av digoksin tilsvarende 7,7 \% av den målte digitoksinkonsentrasjonen i de 172 prøvene hvor begge glykosider ble påvist.

Ved tilstedeværelse av både digitoksin og digoksin i samme prøve estimerte vi den totale serumkonsentrasjonen av digitalis som digoksinekvivalenter. Vi konverterte serumkonsentrasjoner av digitoksin til digoksinekvivalenter ved å dividere den målte serumkonsentrasjonen med $10(7,9)$ for å veie opp for potensforskjellen mellom de to medikamentene. Deretter summerte vi serumkonsentrasjonen av digoksin og konvertert digitoksin for å beregne totalkonsentrasjonen angitt som digoksinekvivalenter. 
Vi beregnet endringen i digitalisnivå i forbindelse med byttet som ratio mellom serumkonsentrasjoner av digoksinekvivalenter før og etter byttet hos hver pasient. Når ratioen var i området o,8-1,25, ble konsentrasjonen regnet som stabil (10).

Basert på målte serumkonsentrasjoner ble pasientene inndelt i fire grupper: individer med antatt subterapeutisk, terapeutisk, supraterapeutisk og toksisk serumkonsentrasjon før og etter byttet. De fire gruppene med tilhørende serumkonsentrasjonsintervaller er definert i tabell 1.

\section{Tabell 1}

Definisjoner av antatt subterapeutiske, terapeutiske, supraterapeutiske og toksiske serumkonsentrasjoner av digitoksin og digoksin brukt i artikkelen. Definisjonene bygger på tidligere og aktuelle referanseområder $(11,12)$.

\begin{tabular}{|c|c|c|}
\hline & \multicolumn{2}{|c|}{ Digitoksin (nmol/l) Digoksin (nmol/l) } \\
\hline Referanseområde (12) & $8-15$ & $0,6-1,2$ \\
\hline Subterapeutisk serumkonsentrasjon & $<8$ & $<0,6$ \\
\hline Terapeutisk serumkonsentrasjon & $8-15$ & $0,6-1,2$ \\
\hline Supraterapeutisk serumkonsentrasjon ${ }^{1}$ & $15-33$ & $1,2-2,5$ \\
\hline Toksisk serumkonsentrasjon $^{1}$ & $>33$ & $>2,5$ \\
\hline
\end{tabular}

${ }^{1}$ Grensen mellom supraterapeutisk og toksisk serumkonsentrasjon er satt ved referanseområdenes øvre grense før 2007, dvs. $33 \mathrm{nmol} / \mathrm{l}$ for digitoksin og 2,5 nmol/l for digoksin (11)

Siden vi brukte data fra analyser av pasientprøver, søkte vi forhåndsgodkjenning fra Regional komité for medisinsk og helsefaglig forskningsetikk. Komiteen konkluderte i sitt svar datert 1.3.2017 at studien var å anse som en kvalitetssikringsstudie og at den derfor lå utenfor deres mandat. Studien ble så forelagt Personvernombudet for forskning ved St. Olavs hospital, der den ble godkjent 15.5.2017.

\section{Resultater}

Totalt 304 pasienter, 1686 prøver og 1858 serumkonsentrasjonsanalyser av digitoksin og digoksin ble inkludert i studien ( $\operatorname{tab} 2$ ). Mediantiden fra siste analyse av digitoksin til første analyse av digoksin var 183 døgn (interkvartilbredde:348 døgn). For pasienter som fikk utført flere analyser av digoksin etter byttet $(n=218)$, var mediantiden mellom første og andre prøve $28 \mathrm{~d} ø$ gn. Totalt fikk 52/218 (23,9\%) utført to serumkonsentrasjonsmålinger av digoksin innenfor tidsintervallet på én uke som var anbefalt av Legemiddelverket (5).

\section{Tabell 2}

Fordeling av antall pasienter og analyser som er inkludert i studien. Tallene er basert på pasienter som var omfattet av overgangen fra digitoksin til digoksin i forbindelse med avregistreringen av digitoksin, og som fikk målt serumkonsentrasjoner av både digitoksin og digoksin ved Avdeling for klinisk farmakologi ved St. Olavs hospital i perioden 1.1.2011-31.12.2O13.

\begin{tabular}{|lr|}
\hline Pasienter & \\
\hline Totalt & $304(100)$ \\
\hline Kvinner & $166(54,6)$ \\
\hline Alder i år, gjennomsnitt (spredning) & $81(43-100)$ \\
\hline \multicolumn{2}{|c|}{ Aldersgrupper $\quad<$ 70 år } \\
\hline \multicolumn{2}{|c|}{$33(10,9)$} \\
\hline
\end{tabular}




\begin{tabular}{|c|c|c|}
\hline & 70-79 år & $87(28,6)$ \\
\hline & $\geq 80$ år & $184(60,5)$ \\
\hline \multicolumn{3}{|l|}{ Analyser } \\
\hline Totalt $^{1}$ & & $1858(100)$ \\
\hline Digitoksin & & $956(51,5)$ \\
\hline Digoksin & & $902(48,5)$ \\
\hline Analyser $\mathrm{pe}$ & , gjennomsnitt (spredning) & $6,1(2-23)$ \\
\hline
\end{tabular}

${ }^{1}$ Det var i alt 1686 prøver, hvorav 172 var analysert både for digitoksin og digoksin

\section{DOSERING}

Ved siste prøvetaking før overgangen var mediandosen av digitoksin $350 \mu \mathrm{g} / \mathrm{uke}$ (interkvartilbredde: $150 \mu \mathrm{g} / \mathrm{uke}$ ). Ved første prøvetaking etter byttet var tilsvarende tall for digoksin $875 \mu \mathrm{g} / \mathrm{uke}$ (interkvartilbredde: $875 \mu \mathrm{g} / \mathrm{uke}$ ). 232/304 pasienter (76,3\%) byttet til en samlet dose digoksin på enten $875 \mu \mathrm{gg} / \mathrm{uke}(108 / 304 ; 35,5 \%)$ eller $1750 \mu \mathrm{g} / \mathrm{uke}(124 / 304 ; 40,8 \%)$. Blant 153 pasienter med en samlet dose digitoksin på $350 \mu \mathrm{g} / \mathrm{uke}$ (den vanligste doseringen), byttet de aller fleste over til digoksindoser på enten $1750 \mu \mathrm{g} / \mathrm{uke}(76 / 153,49,7 \%), 875 \mu \mathrm{g} / \mathrm{uke}$ (54/153, 35,3\%) eller 437,5 $\mathrm{\mu g} / \mathrm{uke}(15 / 153,9,8 \%)$.

\section{KONSENTRASJON}

Fordeling av individuelle pasienters serumkonsentrasjoner ved siste digitoksinanalyse før byttet og første digoksinanalyse etter byttet er gjengitt i figur 1 og tabell 3. Hos 112/304 pasienter (36,8 \%) ble det målt serumkonsentrasjoner over referanseområdet - med 9/304 pasienter (3,0 \%) i toksisk område - i den første prøven etter byttet. Når tidsvinduet ble utvidet til tre måneder etter byttet, var tallene henholdsvis $128 / 304$ pasienter $(42,1 \%)$ og $13 / 304$ pasienter $(4,3 \%)$.

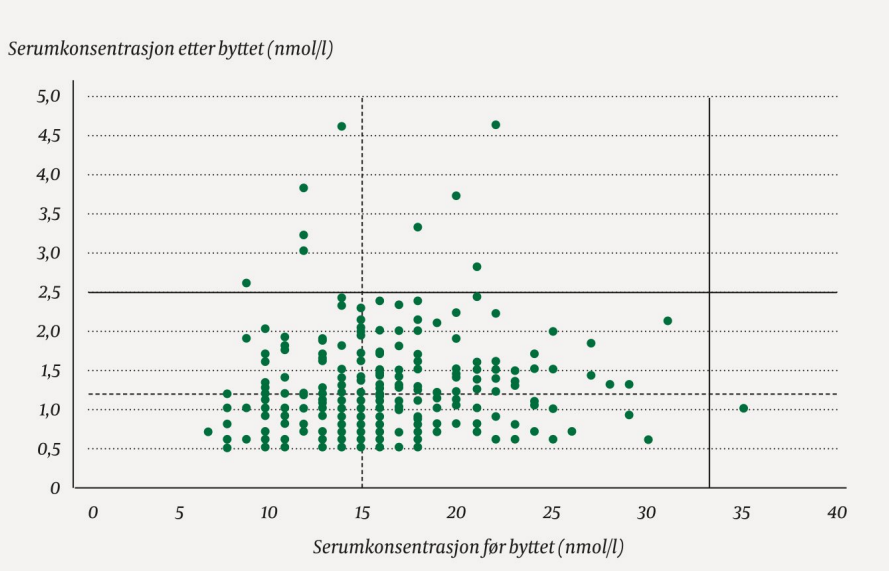

Figur 1 Individuelle serumkonsentrasjoner ved siste digitoksinanalyse før byttet og første digoksinanalyse etter byttet hos 304 pasienter som byttet fra digitoksin til digoksin i forbindelse med avregistreringen av digitoksin $i$ 2011. Digoksinkonsentrasjonene etter byttet er basert på et estimat av samlet serumkonsentrasjon av digitalis, uttrykt som digoksinekvivalenter. De stiplede, svarte linjene markerer overgangen fra terapeutisk til supraterapeutisk serumkonsentrasjon av henholdsvis digitoksin (vertikal stiplet linje) og digoksin (horisontal stiplet linje). De heltrukne, svarte linjene markerer på tilsvarende vis overgangen fra supraterapeutisk til toksisk serumkonsentrasjon.

\section{Tabell 3}

Individuelle serumkonsentrasjoner ved siste digitoksinanalyse før byttet og første digoksinanalyse etter byttet hos 304 pasienter som byttet fra digitoksin til digoksin i forbindelse med avregistreringen av digitoksin i 2011. Nivåinndelingen av 
digoksinkonsentrasjon etter byttet er basert på et estimat av samlet serumkonsentrasjon av digitalis, uttrykt som digoksinekvivalenter.

\begin{tabular}{|lccccc|}
\hline \multicolumn{7}{|c|}{ Etter byttet, antall (\%) } \\
\hline Før byttet & \multicolumn{1}{c|}{ Subterapeutisk Terapeutisk Supraterapeutisk } & Toksisk & $\begin{array}{c}\text { Totalt, } \\
\text { antall }(\%)\end{array}$ \\
\hline Subterapeutisk & 0 & $1(0,3)$ & 0 & 0 & $1(0,3)$ \\
\hline Terapeutisk & $12(3,9)$ & $108(35,5)$ & $46(15,1)$ & $5(1,6)$ & $171(56,3)$ \\
\hline Supraterapeutisk & $4(1,3)$ & $66(21,7)$ & $57(18,8)$ & $4(1,3)$ & $131(43,1)$ \\
\hline Toksisk & 0 & $1(0,3)$ & 0 & 0 & $1(0,3)$ \\
\hline Totalt & $16(5,3)$ & $176(57,9)$ & $103(33,9)$ & $9(3,0)$ & $\begin{array}{c}304 \\
(100)\end{array}$ \\
\hline
\end{tabular}

De 13 som hadde toksiske digoksinnivåer i løpet av de første tre månedene etter byttet, var alle gamle (76-10o år; gjennomsnitt 85,9 år, 10/13 (76,9\%) var over 8o år). Kvinner utgjorde 9/13 (69,2\%). Mediandosering av digoksin var $1750 \mu \mathrm{g} / \mathrm{uke}$ (interkvartilbredde: $250 \mu \mathrm{g} / \mathrm{uke}$ ). Fire pasienter (30,8\%) hadde fått digoksindoser som oversteg Legemiddelverkets anbefalinger. For fire pasienter (30,8\%) ble det ikke funnet flere analyser av digoksin i vår database etter den prøven som viste en toksisk verdi. Av 9/13 pasienter (69,2\%) med mer enn én digoksinanalyse hadde fem supraterapeutiske og fire terapeutiske serumkonsentrasjoner av digoksin ved første prøve etter prøven med forhøyet verdi (ekskludert kontrollprøver tatt samme eller påfølgende dag). Hos 5/13 pasienter $(38,5 \%$ ) ble dosering av digoksin redusert enten midlertidig eller permanent i etterkant av prøven som viste toksisk verdi.

Hos 120 pasienter under 80 år var mediankonsentrasjonen (i digoksinekvivalenter) ved første prøve etter byttet 1,o nmol/l, og hos 184 pasienter $\geq 80$ år 1,2 nmol/l. Ved første prøve etter byttet var gjennomsnittsalder blant pasienter med subterapeutisk serumkonsentrasjon 79,3 år, terapeutisk 80,4 år, supraterapeutisk 81,8 år og toksisk serumkonsentrasjon 85,9 år. Ved siste prøve før byttet var tilsvarende tall 82,o år, 8o,4 år, 80,0 år, og $88, o$ år.

Hos 179/304 pasienter (58,9\%) ble det målt en reduksjon i serumkonsentrasjonen - uttrykt i digoksinekvivalenter - etter byttet, mens 77/304 (25,3\%) hadde uendrede konsentrasjoner (tab 4) (10). Blant pasienter med supraterapeutiske eller toksiske serumkonsentrasjoner av digitoksin før byttet fikk 96/132 pasienter (78,5\%) en reduksjon i konsentrasjonsratio. Totalt $48 / 304$ pasienter $(15,8 \%)$ fikk en $\emptyset$ kt digitalisbelastning etter byttet, og $32 / 48(66,7 \%)$ var over 8 o år.

\section{Tabell 4}

Relative endringer i serumkonsentrasjon fra siste digitoksinanalyse før byttet til første digoksinanalyse etter byttet hos 304 pasienter som byttet fra digitoksin til digoksin i forbindelse med avregistreringen av digitoksin i 2011. Digoksinkonsentrasjonene etter byttet er uttrykt som digoksinekvivalenter.

\begin{tabular}{|ll|}
\hline \multicolumn{2}{|c|}{ Konsentrasjonsratio ${ }^{\mathbf{1}}$ Antall $(\%)$} \\
\hline$<0,25$ & $2(0,7)$ \\
\hline $0,25-0,49$ & $62(20,4)$ \\
\hline $0,50-0,79$ & $115(37,8)$ \\
\hline $0,80-1,24^{2}$ & $77(25,3)$ \\
\hline $1,25-1,99$ & $40(13,2)$ \\
\hline$\geq 2,00$ & $8(2,6)$ \\
\hline
\end{tabular}

${ }^{1}$ Definert som konsentrasjonen i digoksinekvivalenter i den siste prøven tatt mens pasienten brukte digitoksin, dividert på konsentrasjonen i digoksinekvivalenter i den første prøven etter at pasienten hadde byttet til digoksin 


\section{Diskusjon}

Den totale andelen pasienter med konsentrasjoner i terapeutisk område holdt seg relativt stabilt i forbindelse med overgangen. Samtidig gikk andelen pasienter med konsentrasjoner i supraterapeutisk område noe ned, mens andelen i subterapeutisk og toksisk område gikk opp. Den økte forekomsten av pasienter med subterapeutiske serumkonsentrasjoner kan ha sammenheng med at pasienten ikke hadde nådd likevektsnivået for digoksinkonsentrasjonen på prøvetakningstidspunktet. Det er påfallende at kun $35,5 \%$ av alle pasientene var optimalt regulert både før og etter byttet. Dette understreker utfordringene med å benytte legemidler med smalt terapeutisk vindu i klinisk praksis.

Byttet førte til at nærmere tre av fem pasienter fikk en redusert belastning av digitalis. Denne nedgangen bidro til at omtrent halvparten av alle pasienter med supraterapeutiske $(n=131)$ eller toksiske $(n=1)$ serumkonsentrasjoner før byttet, endte innenfor terapeutisk område etter overgangens start. Resultatene kan skyldes at det frem mot byttetidspunktet fremdeles var et «etterslep» av pasienter innstilt på digitoksinnivåer i det tidligere (før 2007) terapiområdet på 15-33 nmol/l (13).

Det mest bekymringsfulle er at andelen pasienter i toksisk område $\varnothing$ kte betydelig i etterkant av overgangen. Hvis andelen pasienter som fikk toksiske serumkonsentrasjoner av digoksin ligger et sted mellom 3,0-4,3\% også utenfor nedslagsområdet vårt, vil det på landsbasis kunne si at 6oo-90o av de drøyt 21 ooo pasientene som var omfattet av overgangen (6), endte opp med toksiske serumkonsentrasjoner etter byttet. Selv om overgangen førte til en nedgang i digitalisbelastning for flertallet av pasientene, kan den også ha satt et betydelig antall pasienter i fare. Det er ikke bare antallet pasienter med toksiske serumkonsentrasjoner i etterkant av byttet som er problematisk, men også omfanget av de enkelte avvikene (fig 1 ): Før byttet fikk kun én pasient målt en toksisk serumkonsentrasjon av digitoksin, og denne konsentrasjonen var marginalt over grenseverdien for toksisk område. Etter byttet var det ni pasienter som fikk målt toksiske serumkonsentrasjoner ved første digoksinanalyse. Av disse hadde syv konsentrasjoner som relativt sett var høyere enn hos pasienten med den høyeste konsentrasjonen før byttet, og to hadde nivåer som var nesten det dobbelte av grensen som markerte toksisk område. Denne lille, men svært utsatte undergruppen pasienter, hvor kvinner over 80 år er overrepresentert, er taperne i bytteprosessen.

Studien antyder, ikke overraskende, at det kan være en sammenheng mellom økende alder og risiko for overdosering med digoksin. Vi så trender som tyder på at pasienter over 80 år hyppigere fikk økte serumkonsentrasjoner sammenlignet med pasienter under 80 år, og at gjennomsnittsalderen økte med serumkonsentrasjon av digoksinekvivalenter.

I forbindelse med innledende dosering av digoksin er det tilsynelatende blitt utvist stor forsiktighet. Av 153 pasienter med en ukedose av digitoksin på $350 \mu \mathrm{g}$, var det bare halvparten som byttet over til den i Legemiddelverkets veileder foreslåtte ukedosen på 1750 $\mu \mathrm{g}$ digoksin (5). Av de resterende pasientene fikk flertallet enten halvparten eller en firedel av den foreslåtte dosen (ramme 1). Forskrivernes forsiktige tilnærming til Legemiddelverkets doseringsforslag har trolig bidratt til at en stor andel av pasientene fikk reduserte serumkonsentrasjoner av digitalis i forbindelse med overgangen og at man unngikk enda flere toksiske konsentrasjoner.

Det er bekymringsfullt at hver tredje pasient ikke fikk utført mer enn én serumkonsentrasjonsanalyse av digoksin i forbindelse med overgangen og at kun 17 \% fikk målt serumkonsentrasjon av digoksin i tråd med Legemiddelverkets anbefalinger. Siden størsteparten av bivirkningene som ses ved digitalisintoksikasjon er uspesifikke, er det utfordrende å knytte aktuelle symptomer og funn til overdoseringer. 
Serumkonsentrasjonsanalyser bør derfor ha en sentral plass i oppfølging av digitalisbehandlede pasienter. Det er en potensiell feilkilde at noen pasienter kan ha seponert digoksin kort tid etter overgangen og dermed bare ha fått utført analysen én gang. Vi har ikke informasjon om hvor mange pasienter som eventuelt kan ha seponert digoksin i løpet av oppfølgingsperioden, og funnet må derfor tolkes med forsiktighet. Det samme gjelder eventuelle prøver som kan ha vært sendt til et annet laboratorium.

\section{STERKE OG SVAKE SIDER}

Materialet i denne studien baserer seg på spontant innsendte prøver for serumkonsentrasjonsanalyse av digitoksin og digoksin. Dette kan være en styrke fordi det gir et inntrykk av fordelingen av serumkonsentrasjoner i en ordinær norsk pasientpopulasjon, men en svakhet fordi det kan skje en seleksjon der det særlig er de eldste eller sykeste som får målt serumkonsentrasjonene regelmessig (13). Imidlertid opplyste både Legemiddelverket (5) og regionalt legemiddelinformasjonssenter (RELIS) (14, 15) om viktigheten av serumkonsentrasjonsanalyser ved overgangen. Dette kan ha bidratt til $\emptyset \mathrm{kt}$ bevissthet rundt og følgelig mer utstrakt bruk av serumkonsentrasjonsanalyser som ledd i oppfølgingen av pasienter, noe som kan ha tilført studien en større og mer variert pasientpopulasjon.

Det finnes en rekke ulike faktorer som påvirker individuelle pasienters respons på digitalisbehandling, både i form av terapieffekt og bivirkninger/toksisitet. Måling av elektrolyttnivåer og kreatininkonsentrasjonen i serum samt kliniske opplysninger om andre sykdomstilstander og inntak av andre og potensielt interagerende legemidler kunne gitt nyttig tilleggsinformasjon. Slike opplysninger var imidlertid i liten grad tilgjengelig i datamaterialet.

Samtlige prøver som inngår i denne studien er blitt sendt til Avdeling for klinisk farmakologi ved St. Olavs hospital for analyse. Det kan imidlertid ikke utelukkes at prøver fra de samme pasientene også har blitt sendt til andre laboratorier. Avhengig av omfanget vil dette kunne påvirke flere av resultatene i studien, deriblant tidsintervallene mellom analysene og totalantallet analyser for den enkelte pasient i løpet av oppfølgingstiden. I august 2012 var det henholdsvis 30 og 29 norske laboratorier som tilbød analyser av digitoksin og digoksin (16). Fortrinnsvis burde data fra alle disse laboratoriene vært inkludert i en studie som denne (17).

Tidsintervallet fra siste inntak av digitoksin/digoksin og frem til prøvetaking varierte i tallmaterialet. Ideelt sett kunne vi ha standardisert konsentrasjonene til 24-timers legemiddelfastende konsentrasjoner, ut fra legemiddelspesifikke halveringstider og angitte tidspunkt på rekvisisjonene. Mange rekvisisjoner manglet imidlertid informasjon om tidspunkt for siste inntak eller tidspunkt for prøvetaking (eller begge deler), og sletting av slike ville medført betydelig datatap. Vi valgte derfor heller å inkludere alle prøvene uavhengig av tidsopplysninger på rekvisisjonen eller fravær av slik informasjon. Siden både digoksin og digitoksin har svært lange halveringstider (henholdsvis to og syv døgn) (12), tror vi ikke variasjoner i prøvetakingsintervall vil ha påvirket de målte konsentrasjonene i særlig grad. I den grad dette er en feilkilde, vil konsekvensen av et endret intervall bli en feilestimering av verdiene som kvantitativt gir størst utslag for digoksin.

En eksklusiv inklusjon av siste digitoksinprøve kan være misvisende, ettersom vi ikke har informasjon om omstendighetene rundt prøvetakingen. Enkelte prøver kan være tatt i situasjoner der pasienten allerede hadde seponert digitoksin. At det var flere med toksiske konsentrasjoner etter byttet til digoksin, kan rett og slett være et uttrykk for at oppstart med digitalispreparater generelt er problematisk.

For å estimere den samlede digitalisbelastningen har vi basert oss på summering av digoksinekvivalenter i situasjoner der pasienter hadde målbare konsentrasjoner av digitoksin og digoksin i samme prøve. Omregningsfaktoren på ti er den samme som ble brukt i artikkelen til Schjøtt og medarbeidere (7) og samsvarer med de potensforskjellene som diskuteres av Smith (9). Konseptet er likevel usikkert og savner basis i 
ekvivalensstudier. En annen omregningsfaktor, for eksempel 12 eller 13, som kanskje virker mer logisk ut fra referanseområdene $(\operatorname{tab} 1)(11,12)$, ville ikke ha endret resultatene nevneverdig. Totalt sett er 172 av 902 digoksinanalyser påvirket av denne problemstillingen.

Kryssreaktivitet ved digoksinanalyser byr på problemer med tanke på fortolkning av datamaterialet. Ved å ta høyde for kryssreaktiviteten som oppgis for metoden på 7,7 \% (8) presenterer vi antakelig relativt konservative anslag.

\section{Konklusjon}

De digoksindosene pasientene byttet til, var i et stort antall tilfeller lavere enn hva Legemiddelverket anbefalte (ramme 1). Dette kan ha bidratt til at flertallet av pasienter fikk reduserte serumkonsentrasjoner av digitalis som følge av byttet. Andelen pasienter i terapeutisk område holdt seg relativt stabilt, og andelen pasienter i supraterapeutisk område ble redusert. Til tross for at byttet for mange førte til en reduksjon i dosering og serumkonsentrasjon, økte også antallet med toksisk serumkonsentrasjon (fig 1, tab 3), slik at et betydelig antall pasienter på landsbasis kan ha blitt utsatt for fare som følge av overgangen. Dette inkluderer pasienter som tidligere var velregulert med digitoksinterapi.

\section{HOVEDBUDSKAP}

Etter avregistreringen av digitoksin i desember 2011 byttet brukerne til digoksin

Vi fulgte 304 pasienter som ble monitorert med serumkonsentrasjonsmålinger under byttet Kun 108 pasienter (35,5\%) hadde terapeutiske digitaliskonsentrasjoner i serum både før og etter byttet

Andelen pasienter med toksisk forhøyede digitalisnivåer i serum økte fra o,3 \% før byttet til 3,0 \% etter byttet

\section{LITTERATUR:}

1. Ziff OJ, Kotecha D. Digoxin: The good and the bad. Trends Cardiovasc Med 2016; 26: 585 - 95. [PubMed][CrossRef]

2. Digitalis Investigation Group. The effect of digoxin on mortality and morbidity in patients with heart failure. N Engl J Med 1997; 336: 525-33. [PubMed][CrossRef]

3. Rathore SS, Curtis JP, Wang Y et al. Association of serum digoxin concentration and outcomes in patients with heart failure. JAMA 2003; 289: 871 - 8. [PubMed][CrossRef]

4. Lely AH, van Enter CH. Large-scale digitoxin intoxication. BMJ 1970;3: 737 - 40. [PubMed][CrossRef]

5. Statens legemiddelverk. Overgang fra digitoksin til digoksin hos voksne.

https://legemiddelverket.no/nyheter/overgang-fra-digitoksin-til-digoksin-hos-voksne (20.1.2018).

6. Haga C, Opdal MS, Tuv SS et al. Legemiddelsikkerhet ved bytte av digitalispreparat i Norge. Tidsskr Nor Legeforen 2016; 136:1714 - 8. [PubMed][CrossRef]

7. Schjøtt J, Torgauten HM, Bjånes TK. Shortage of digitoxin and switching to digoxin in Norway: a retrospective study of blood samples submitted to a clinical pharmacology laboratory. Basic Clin Pharmacol Toxicol 2017; 121: 74 - 7. [PubMed][CrossRef]

8. Roche Diagnostics. Digoxin (DIG). I: Pakningsvedlegg for digoksinanalyser på Cobas Integra 40o/80o analyseinstrument (v11 NO). Mannheim: Roche Diagnostics GmbH, 2012: 1-4.

9. Smith TW. Pharmacokinetics, bioavailability and serum levels of cardiac glycosides. J Am Coll Cardiol 1985; 5 (suppl A): 43A - 5oA. [PubMed][CrossRef]

10. Committee for Medicinal Products for Human Use. Guideline on the investigation of bioequivalence. London: European Medicines Agency, 2010:15. 
http://www.ema.europa.eu/docs/en_GB/document_library/Scientific_guideline/2010/o1/WC50007003 9.pdf(20.1.2018).

11. Brørs O. Legemiddelanalyser og rusmiddelanalyser. I: Norsk legemiddelhåndbok for helsepersonell 2004. Oslo: Foreningen for utgivelse av Norsk legemiddelhåndbok, 2004:1601-8.

12. Osnes J-B, Aass H. Hjerteglykosider. I: Norsk legemiddelhåndbok for helsepersonell 2007. Oslo: Foreningen for utgivelse av Norsk legemiddelhåndbok, 2007: 1015-18.

13. Hønnås A, Reimers A, Spigset O. Dosering av digitoksin i klinisk praksis. Tidsskr Nor Legeforen 2010; 130: 1334 - 6. [PubMed][CrossRef]

14. RELIS. Overgang fra digitoksin til digoksin.

https://relis.no/Aktuelt/Arkiv/2012/Overgang_fra_digitoksin_til_digoksin/(20.1.2018).

15. Giverhaug T, Halvorsen KH. Praktiske råd for sikrere bytte fra digitoksin til digoksin.

https://relis.no/Bivirkninger/Nytt_om_bivirkninger/2012/Praktiske_rad_for_sikrere_bytte_fra_digito ksin_til_digoksin(20.1.2018).

16. Westin AA, Larsen R-A, Espnes KA et al. Legemiddelanalyser i Norge. Tidsskr Nor Legeforen 2012; 132: 2382 - 7. [PubMed][CrossRef]

17. Slørdal L, Eggen AE. Digitalisering ad modum Statens legemiddelverk. Tidsskr Nor Legeforen 2016; 136: 170o. [PubMed][CrossRef]

Publisert: 1. oktober 2018. Tidsskr Nor Legeforen. DOI: 10.4045/tidsskr.18.0093

Mottatt 25.1.2018, første revisjon innsendt 20.4.2018, godkjent 27.6.2018.

(C) Tidsskrift for Den norske legeforening 2020. Lastet ned fra tidsskriftet.no 